\title{
Soil Heavy Metal Pollution Evaluation around Mine Area with Traditional and Ecological Assessment Methods
}

\author{
Han Zhou, Xiaoying Guo* \\ Institute of Agricultural Engineering, Anhui Academy of Agricultural Science, Hefei, China \\ Email: "gxy2@mail.ustc.edu.cn
}

Received August 2015

\begin{abstract}
As a widespread problem, heavy metals contamination in soil has drawn considerable study interest, especially for the farmlands around mine area. A variety of pollution evaluation methods have been compared including both traditional physical and chemical analysis methods as well as ecological assessment methods. And the combination of multiple assessment methods was recommended to get a comprehensive and through soil heavy metal pollution evaluation.
\end{abstract}

\section{Keywords}

Soil Heavy Metal, Pollution Evaluation, Microorganisms

\section{Introduction}

Heavy metals contamination in soil has become a widespread problem all over the world. As a consequence of rapid social and economic development over the past several decades, soil pollution by heavy metals has been both serious and widespread in China [1]-[3]. Although heavy metals may occur naturally in soil based on the origin of soil, additional contributions come from various source including agricultural activities, urbanization, industrialization, and mine activities. Among these, mine activity is considered as one of the most influential anthropogenic activities which results in changes in landscapes, destruction of habitats, contamination of soil and water, and degradation of land resources [4]-[7].

Even after the cessation of the mining works, huge tailing ponds as a result of the accumulation of the wastes remain in the area which may extend in some cases over hundred hectares, are now abandoned without any particular safety measures and with a high environmental impact on the surrounding ecosystems and populations [8]-[10].

In order to evaluate the damages against environment that mining activities produce, methods to assess the pollutions are necessary. These must be based on preliminary studies about waste properties, heavy metals content and theirs relation to the environment [11].

The determination of the level of pollution and understanding of spatial variability of topsoil heavy metal

"Corresponding author.

How to cite this paper: Zhou, H. and Guo, X.Y. (2015) Soil Heavy Metal Pollution Evaluation around Mine Area with Traditional and Ecological Assessment Methods. Journal of Geoscience and Environment Protection, 3, 28-33.

http://dx.doi.org/10.4236/gep.2015.310005 
concentration in tailing ponds is critical for environmental management and remediation [12]-[14]. The evaluation of the spatial variability of waste properties is essential to achieve a better understanding of complex relations between the factors. This is very importance for successful land management [15]-[17].

Numerous methods have been developed to evaluate the impact of pollutions as well as the ecology and health hazard they cause. This study would summarize the methods used to assess the soil heavy metal pollution.

\section{Traditional Soil Heavy Metal Pollution Evaluation}

Traditional soil heavy metal pollution evaluation includes numerous mensuration methods to determine the variety and content of heavy metals in soil samples.

\subsection{Soil Heavy Metal Assessment}

The first thing for mine area soil properties analysis is collecting representative soil samples located in the vicinity of mines, usually the investigation zone would be divided into different zones [18]-[20]. Every study zone was further divided into a grid of cells using a systematic grid sampling method with regularly spaced intervals. Afterwards, soil samples were collected in the field via random sampling methods and then mixed thoroughly to give a composite sample. As the assess subject are usually farming soils, samples were usually collected to a depth of 0 - $15 \mathrm{~cm}$ [21] [22], 0 - $20 \mathrm{~cm}$ [23]-[25] and 20 - $40 \mathrm{~cm}$ [26].

After collection, soil samples were air-dried at room temperature, and then pulverized and sieved. After digested with a typical concentrated acid mixture (e.g. $\mathrm{HNO}_{3}-\mathrm{HClO}_{4}-\mathrm{HF}$ or $\mathrm{HNO}_{3}-\mathrm{HClO}_{4}-\mathrm{HCl}$ or

HCl- $\mathrm{HNO}_{3}-\mathrm{HF}-\mathrm{HClO}_{4}$ ) [20] [24] [27], the soil solutions were treated by a variety of analytical methods to determine the kinds and contents of heavy metals. Those analytical methods usually concerning precise analysis equipment such as fluorescence spectrophotometer in atomic fluorescence spectrophotometry [28] [29], spectrometer in inductively coupled plasma atomic emission spectrometry [30] [31], and absorption spectrometers in atom absorption spectrometry.

However the pollution statues of soil would not stay static, as the mining activity continues, more pollution would emerge; even with mining activity finished, tailing waste could be carried away by underground water streams. Moreover the state of heavy metals within soil would change along with soil condition, and soluble heavy metals would move with water migrations. The pollution developments of different places share no unanimous trend for their highly dependence on geography environment and climate conditions.

The evaluation and prediction of future pollution statues are of great significance for they help proposing better plans for pollution abatement. The most common method in kinetic pollution evolution are multivariate statistical analysis [16]: samples were usually taken through a calculated distribution of time or location concerning the geography environment and climate conditions of the test field and contents of each pollutants tested. The distribution of each pollutant could be used to locate the source and development trend of pollution or the variation of pollution status as time passes in order to predicate the development of the pollution. Along with the advance of technology, new techniques have been applied to the evaluation of heavy metal pollution: geographical information system (GIS) could be applied to enhance multivariate statistical analysis [4] [32] to better evaluate the pollution statues by provide detailed information of heavy metals behavior as well as identify highest risk sites where main efforts of reclamation and monitoring should be realized.

\subsection{Ecology and Health Hazard Assessment}

Heavy metal pollution not only degrades the quality of air, water bodies, and food crops, but also threatens the health and well-being of animals and human beings through food chain [33] [34]. For example, as a non-essential element to human body, the excessive intake of $\mathrm{Pb}$ can damage nervous, skeletal, circulatory, enzymatic, endocrine, and immune systems of those exposed to it [35]; chronic exposure to Cd can have adverse effects such as lung cancer, pulmonary adenocarcinomas, prostatic proliferative lesions, bone fractures, kidney dysfunction, and hypertension, while the chronic effects of As consist of dermal lesions, peripheral neuropathy, skin cancer, and peripheral vascular disease [36].

As a consequence, vegetation tissue of crops and vegetables grow in contamination areas are also assessment subjects to prevent health damage the pollution might cause [37]. However this assessment is a post measure which is very inefficient. 
On the other hand, human health risk assessment are usually done through a series of calculation to estimating the nature and probability of adverse health effects in humans who may be exposed to chemicals in contaminated environmental media [38]. For heavy metals in contaminated soils, ingestion and dermal absorption play the most important roles among the potential exposure pathways [39].

However this estimation as well as the traditional assessment method lacks the direct impression on the degree of health risk and the damage the pollution has done to the ecosystem.

\section{Ecology Soil Heavy Metal Pollution Evaluation}

In addition to traditional assessment method, many new methods have also been developed to evaluate the statues of heavy metal pollution. Microorganisms in soil which could not only reflect soil environment, but they take part in soil variations as well has been considered as an idea subject in evaluation and prediction of soil development.

\subsection{Nematodes Assessment}

Soil disturbances affect the structure communities of soil organisms, and the deterioration of the soil environment could be evaluated by studying these changes. Soil nematodes are suitable for such purposes for their abundance and high diversity. Soil nematodes who respond rapidly to disturbances play important roles in soil ecological processes such as primary production, nutrient cycling, decomposition; several trophic groups are well-adapted to a wide range of environmental conditions. All these features make them appropriate for evaluation and prediction of soil conditions [40] [41].

In particular, the assessment of changes in the structure and function of nematode communities can be used to evaluate disturbances in soil ecosystems [42] or to study the effect of heavy metal pollution [43]: the insufficiency of trophic groups and long-living persistor-type nematodes around the mining area, especially in relation to $\mathrm{Pb}$ and $\mathrm{Zn}$ pollution, have recently been detected [44] [45], and the activities and species richness of nematode communities have diminished in polluted soils in accordance with specific heavy metals and their concentrations have also been observed [44] [46].

Several indices are used as tools to assess these changes. Ecological indices which could provide information about the diversity of nematode communities are based on abundance, species richness and equitability amongst taxa [47].

Functional indices are based on trophic preference(plant feeders, bacterial feeders, fungal feeders, root-fungal feeders, omnivores and predators) and life strategy assessed with a c-p (colonizer-persister) scale from 1 to 5 (from extreme r- to extreme K-strategists, where the coloniser nematodes are considered opportunist and stresstolerant, whereas the persisters are sensitive), and the relative weighted abundance of functional guilds (based on feeding habits and a c-p classification, weighted according to their indicator characteristics). They could provide information on the functioning and condition of the nematode food web [48].

The new metabolic footprint concept improves functional indices as they help estimate the biomass and metabolic activity for each functional group of the food web, and also provide metrics for the magnitudes of the ecosystem functions and services provided by components of the nematode soil food web [49].

\subsection{Enzyme Assessment}

Soil enzymes play a fundamental role in organic mattered composition and in plant nutrient cycling. The activities of enzymes that participate in nitrogen transformation, such as urease, can be used as a measure of the intensity of nitrogen transformation that is occurring in a given environment and can indicate the availability of different nitrogen compounds to plants [50].

Soil enzyme activity is often used as an indicator of the functioning of soil ecosystems. In addition, enzymes are potential indicators of anthropogenic activities in soil environments [51]-[54]. Furthermore, enzyme activities can be used predict the variation trend of soil conditions, for example, urease and invertase whose direct basic functions are nutrients cycling in soils can be used to evaluate soil pollution condition as well as predict the development of soil statues [55].

However, there are relatively little data available from studies of the relationship between enzyme activity and soil properties under specific conditions that include chronic pollution with $\mathrm{Zn}, \mathrm{Pb}$ and $\mathrm{Cd}$, soils of different age, 
and soils with a diversified vegetation cover. As a novel analysis method, enzyme assessments are usually conducted along with traditional assessment method.

\section{Conclusions}

For a considerable time, soil was considered as a means with unlimited capacity to accumulate pollutants without immediately posing harmful effects for the environment or human health. However, that thought has been proved to be wrong. As a consequence of growing human activities, heavy metals in soils have become an alarming threat to both the ecosystem and human health. Ways of evaluate and predict the development of heavy metals pollution have been studied in order to restrain the expansion of pollution and avoid health risk.

Among all the evaluation methods, tradition physical and chemical analysis method proved to be most reliable and straight forward. However without mass of data, this method lacks the ability to predict the development of pollution, and the assessment usually concerns precise analysis equipment.

As for the alternative microorganism analysis methods, as the participants of soil circulation of materials, the status of microorganism could not only reflect the condition of soil, but the development could be predicted as well, however as a novel analysis method. They still lack the data base to ensure the actual contents of each pollutant. So these assessments are usually used along with traditional assessment methods.

\section{References}

[1] Cheng, S. (2003) Heavy Metal Pollution in China: Origin, Pattern and Control. Environ. Sci. Pollut. Res. Int., 10, 192-198. http://dx.doi.org/10.1065/espr2002.11.141.1

[2] Wang, Q., Dong, Y., Cui, Y. and Liu, X. (2001) Instances of Soil and Crop Heavy Metal Contamination in China. Soil Sediment Contam, 10, 497-510. http://dx.doi.org/10.1080/20015891109392

[3] Li, Z., Ma, Z., Jan, T., Der Kuijp, V., Yuan, Z. and Huang, L. (2014) A Review of Soil Heavy Metal Pollution from Mines in China: Pollution and Health Risk Assessment. Sci. Total Environ., 468-469, 843-853. http://dx.doi.org/10.1016/j.scitotenv.2013.08.090

[4] Acosta, J.A., Faz, A., Martínez-Martínez, S., Zornoza, R., Carmona, D.M. and Kabas, S. (2011) Multivariate Statistical and GIS-Based Approach to Evaluate Heavy Metals Behavior in Mine Sites for Future Reclamation. J. Geochemical Explor., 109, 8-17. http://dx.doi.org/10.1016/j.gexplo.2011.01.004

[5] Moreno-Jiménez, E., García-Gómez, C., Oropesa, A.L., Esteban, E., Haro, A., Carpena-Ruiz, R., Tarazona, J.V., Peñalosa, J.M. and Fernández, M.D. (2011) Screening Risk Assessment Tools for Assessing the Environmental Impact in an Abandoned Pyritic Mine in Spain. Sci. Total Environ., 409, 692-703. http://dx.doi.org/10.1016/j.scitotenv.2010.10.056

[6] Komnitsas, K. and Modis, K. (2006) Soil Risk Assessment of As and Zn Contamination in a Coal Mining Region Using Geostatisretics. Sci. Total Environ., 371, 190-196. http://dx.doi.org/10.1016/j.scitotenv.2006.08.047

[7] Zhou, J.-M., Dang, Z., Cai, M.-F. and Liu, C.-Q. (2007) Soil Heavy Metal Pollution Around the Dabaoshan Mine, Guangdong Province, China. Pedosphere, 17, 588-594. http://dx.doi.org/10.1016/S1002-0160(07)60069-1

[8] Antonio, J., Martín, R., Gutiérrez, C., Escuer, M., García-González, M.T., Campos-Herrera, R. and Águila, N. (2014) Effect of Mine Tailing on the Spatial Variability of Soil Nematodes from Lead Pollution in La Union (Spain). Sci. Total Environ., 473-474, 518-529. http://dx.doi.org/10.1016/j.scitotenv.2013.12.075

[9] Meza-Figueroa, D., Maier, R.M., de la O-Villanueva, M., Gómez-Alvarez, A., Moreno-Zazueta, A., Rivera, J., Campillo, A., Grandlic, C.J., Anaya, R. and Palafox-Reyes, J. (2009) The Impact of Unconfined Mine Tailings in Residential Areas from a Mining Town in a Semi-Arid Environment: Nacozari, Sonora, Mexico. Chemosphere, 77, 140-147. http://dx.doi.org/10.1016/j.chemosphere.2009.04.068

[10] Mudd, G.M. (2007) An Analysis of Historic Production Trends in Australian Base Metal Mining. Ore Geol. Rev., 32, 227-261. http://dx.doi.org/10.1016/j.oregeorev.2006.05.005

[11] Markus, J. and McBratney, A.B. (2001) A Review of the Contamination of Soil with Lead II. Spatial Distribution and Risk Assessment of Soil Lead. Environ. Int., 27, 399-411.

[12] Gomez-Ros, J.M., Garcia, G. and Peñas, J.M. (2013) Assessment of Restoration Success of Former Metal Mining Areas after 30 Years in a Highly Polluted Mediterranean Mining Area: Cartagena-La Unión. Ecol. Eng., 57, 393-402. http://dx.doi.org/10.1016/j.ecoleng.2013.04.044

[13] Krishna, A.K., Mohan, K.R., Murthy, N.N., Periasamy, V., Bipinkumar, G., Manohar, K. and Rao, S.S. (2013) Assessment of Heavy Metal Contamination in Soils around Chromite Mining Areas, Nuggihalli, Karnataka, India. Environ. Earth Sci., 70, 699-708. http://dx.doi.org/10.1007/s12665-012-2153-6 
[14] González, I., Galán, E. and Romero, A. (2011) Assessing Soil Quality in Areas Affected by Sulfide Mining. Application to Soils in the Iberian Pyrite Belt (SW Spain). Minerals, 1, 73-108. http://dx.doi.org/10.3390/min1010073

[15] Burgos, P., Madejón, E., Pérez-de-Mora, A. and Cabrera, F. (2008) Horizontal and Vertical Variability of Soil Properties in a Trace Element Contaminated Area. Int. J. Appl. Earth Obs. Geoinf., 10, 11-25. http://dx.doi.org/10.1016/j.jag.2007.04.001

[16] Ma, Z., Li, T., Qu, C., Bi, J. and Huang, L. (2014) Evaluation and Source Identification of Trace Element Contamination of Soils in the Qixia Lead-Zinc Mining Area, Jiangsu, China. J. Soils Sediments, 14, 1703-1712. http://dx.doi.org/10.1007/s11368-014-0900-X

[17] Zhang, C., Li, Z., Yang ,W., Pan, L., Gu, M. and Lee, D. (2013) Assessment of Metals Pollution on Agricultural Soil Surrounding a Lead-Zinc Mining Area in the Karst Region of Guangxi, China. Bull. Environ. Contam. Toxicol., 90, 736-741. http://dx.doi.org/10.1007/s00128-013-0987-6

[18] Li, J., Yin, R., Luo, Y., Lu, Y. and Zhang, L. (2010) Assessment of Heavy Metal Contamination of Soils in Daxin Manganese Mine. Guangxi. Env. Sci Technol, 33, 183-186.

[19] Yin, R., Luo, Y., Li, J., Luo, W. and Zhu, Y. (2008) Evaluation of the Potential Ecological Risk of Heavy Metal Pollution in Soil and Bioaccumulation Characteristics of Dominant Plants in Siding Pb-Zn Mine. J Agro-Enviro Sci, 27, 2158-2165.

[20] Zhao, R., Guo, W., Bao, Y., Yang, H. and Wang, J. (2012) Characteristics of Heavy Metals in Soils from Bainaimiao Copper Mining Area of Grassland Ecosystem in Inner Mongolia. Chin J Soil Sci, 43, 496-500.

[21] Liu, X., Zhou, D., Hao, X., Si, Y., Cang, L. and Wang, Y. (2007) Heavy Metal Pollution of the Environment in Jiuhua Copper Orefield. Soils, 30, 551-555.

[22] Wu, Y., Xu, Y., Zhang, J. and Hu, S. (2010) Evaluation of Ecological Risk and Primary Empirical Research on Heavy Metals in Polluted Soil over Xiaoqinling Gold Mining Region, Shaanxi, China. Trans Nonferrous Met Soc China, 20, 688-694. http://dx.doi.org/10.1016/S1003-6326(09)60199-0

[23] Guo, W., Zhao, R., Zhang, J., Bao, Y., Wang, H. and Yang, M. (2011) Distribution Characteristic and Assessment of Soil Heavy Metal Pollution in the Iron Mining of Baotou in Inner Mongolia. Env. Sci, 32, 3099-3105.

[24] Liu, G., Liang, C., Du, L., Chen, X. and Wang, F. (2006) Primary Study of Heavy Metal Contamination of Soil in the Area of Hongtou Mountains. Chin Agric Sci Bull, 22, 364-367.

[25] Zhang, X.Y., Tang, L.S., Zhang, G. and Wu, H.D. (2009) Heavy Metal Contamination in a Typical Mining Town of a Minority and Mountain Area, South China. Bull. Environ. Contam. Toxicol., 82, 31-38. http://dx.doi.org/10.1007/s00128-008-9569-4

[26] Hui, Y., Zhang, F., Wang, Y., Guo, K., Zhang, J. and Tan, C. (2011) The Current Situation of Heavy Metal Pollution in Copper-Tailings Reservoir of Fenghuang Mountain in Tongling City. J Anhui Agri Sci, 39, 14268-14269.

[27] Li, J., Yin, R., Luo, Y., Lu, Y. and Zhang, L. (2010) Assessment of Heavy Metal Contamination of Soils in Daxin Manganese Mine, Guangxi. Env. Sci Technol, 33, 183-186.

[28] Shi, P., Wang, E., Wei, Z. and Yang, Z. (2010) Assessment of the Heavy Metal Soil Pollution in Qingchengzi LeadZinc Mine Area. Met. Mine, 4, 172-175.

[29] Zhu, Z., Xiong, S., Chen, J.B., Shen, B., Zhou, J. and Liu, F. (2007) Heavy Metal Concentrations of Soils in Lala Copper Mine and Heavy Metal Contamination. Earth Env., 35, 261-266.

[30] Feng, X., Yan, S., Deng, S. and Zhu, Y. (2011) On the Combined Forms of the Heavy Metals in the Soil of the Tungsten Ore. Nonferrous Met. Sci Eng, 2, 64-69.

[31] Li, H., Yan, S. and Cui, L. (2008) Heavy Metal Soil Pollution Assessment of Huainan Xinji Mining Area. Min Saf Env. Prot, 35, 36-38.

[32] Facchinelli, A., Sacchi, E. and Mallen, L. (2001) Multivariate Statistical and GIS-Based Approach to Identify Heavy Metal Sources in Soils. Environ. Pollut., 114, 313-324. http://dx.doi.org/10.1016/S0269-7491(00)00243-8

[33] Dong, J., Yang, Q., Sun, L., Zeng, Q., Liu, S., Pan, J. and Liu, X. (2011) Assessing the Concentration and Potential Dietary Risk of Heavy Metals in Vegetables at a Pb/Zn Mine Site. China Environ. Earth Sci., 64, 1317-1321. http://dx.doi.org/10.1007/s12665-011-0992-1

[34] Nabulo, G., Young, S.D. and Black, C.R. (2010) Assessing Risk to Human Health from Tropical Leafy Vegetables Grown on Contaminated Urban Soils. Sci. Total Environ., 408, 5338-5351. http://dx.doi.org/10.1016/j.scitotenv.2010.06.034

[35] Zhang, X., Yang, L., Li, Y., Li, H., Wang, W. and Ye, B. (2012) Impacts of Lead/Zinc Mining and Smelting on the Environment and Human Health in China. Environ. Monit. Assess., 184, 2261-2273. http://dx.doi.org/10.1007/s10661-011-2115-6

[36] Zukowska, J. and Biziuk, M. (2008) Methodological Evaluation of Method for Dietary Heavy Metal Intake. J. Food 


\section{Sci., 73. http://dx.doi.org/10.1111/j.1750-3841.2007.00648.x}

[37] Dong, J., Yu, M. and Bian, Z. (2012) The Safety Study of Heavy Metal Pollution in Wheat Planted in Reclaimed Soil of Mining Areas in Xuzhou, China. Environ. Earth Sci., 66, 673-682. http://dx.doi.org/10.1007/s12665-011-1275-6

[38] NRC (1983) Risk Assessment in the Federal Government: Managing the Process.

[39] Fryer, M., Collins, C.D., Ferrier, H., Colvile, R.N. and Nieuwenhuijsen, M.J. (2006) Human Exposure Modelling for Chemical Risk Assessment: A Review of Current Approaches and Research and Policy Implications. Environ. Sci. Policy, 9, 261-274. http://dx.doi.org/10.1016/j.envsci.2005.11.011

[40] Neher, D.A. (2001) Role of Nematodes in Soil Health and Their Use as Indicators. J. Nematol., 33, 161-168.

[41] Yeates, G.W. and Bongers, T. (1999) Nematode Diversity in Agroecosystems. Agric. Ecosyst. Environ., 74, $113-135$. http://dx.doi.org/10.1016/S0167-8809(99)00033-X

[42] Bongers, T. and Ferris, H. (1999) Nematode Community Structure as a Bioindicator in Environmental Monitoring. Trends Ecol. Evol., 14, 224-228. http://dx.doi.org/10.1016/S0169-5347(98)01583-3

[43] Georgieva, S.S., McGrath, S.P., Hooper, D.J. and Chambers, B.S. (2002) Nematode Communities under Stress: The Long-Term Effects of Heavy Metals in Soil Treated with Sewage Sludge. Appl. Soil Ecol., 20, $27-42$. http://dx.doi.org/10.1016/s0929-1393(02)00005-7

[44] Park, B., Lee, J., Ro, H. and Ho, Y. (2011) Effects of Heavy Metal Contamination from an Abandoned Mine on Nematode Community Structure as an Indicator of Soil Ecosystem Health. Appl. Soil Ecol., 51, 17-24. http://dx.doi.org/10.1016/j.apsoil.2011.08.006

[45] Shao, Y., Zhang, W., Shen, J., Zhou, L., Xia, H., Shu, W., Ferris, H. and Fu, S. (2008) Nematodes as Indicators of Soil Recovery in Tailings of a Lead/Zinc Mine. Soil Biol. Biochem., 40, 2040-2046. http://dx.doi.org/10.1016/j.soilbio.2008.04.014

[46] Salamun, P., Renco, M., Kucanova, E., Brázova, T., Papajova, I., Miklisova, D. and Hanzelová, V. (2012) Nematodes as Bioindicators of Soil Degradation Due to Heavy Metals. Ecotoxicology, 21, 2319-2330. http://dx.doi.org/10.1007/s10646-012-0988-y

[47] Höss, S., Claus, E., Von der Ohe, P.C., Brinke, M., Güde, H., Heininger, P. and Traunspurger, W. (2011) Nematode Species at Risk-A Metric to Assess Pollution in Soft Sediments of Freshwaters. Environ. Int., 37, 940-949.

[48] Ferris, H., Bongers, T. and De Goede, R.G.M. (2001) A Framework for Soil Food Web Diagnostics: Extension of the Nematode Faunal Analysis Concept. Appl. Soil Ecol, 18, 13-29. http://dx.doi.org/10.1016/S0929-1393(01)00152-4

[49] Ferris, H. (2010) Form and Function: Metabolic Footprints of Nematodes in the Soil Food Web. Eur. J. Soil Biol, 46, 97-104. http://dx.doi.org/10.1016/j.ejsobi.2010.01.003

[50] Iannelli, R., Bianchi, V., Macci, C., Peruzzi, E., Chiellini, C., Petroni, G. and Masciandaro, G. (2012) Assessment of Pollution Impact on Biological Activity and Structure of Seabed Bacterial Communities in the Port of Livorno (Italy). Sci. Total Environ, 426, 56-64. http://dx.doi.org/10.1016/j.scitotenv.2012.03.033

[51] Hinojosa, M.B., Carreira, J., García-Ruíz, R. and Dick, R.P. (2004) Soil Moisture Pre-Treatment Effects on Enzyme Activities as Indicators of Heavy Metal-Contaminated and Reclaimed Soils. Soil Biol. Biochem, 36, 1559-1568. http://dx.doi.org/10.1016/j.soilbio.2004.07.003

[52] Izquierdo, I., Caravaca, F., Alguacil, M.M., Hernández, G. and Roldán, A. (2005) Use of Microbiological Indicators for Evaluating Success in Soil Restoration after Revegetation of a Mining Area under Subtropical Conditions. Appl. Soil Ecol., 30, 3-10. http://dx.doi.org/10.1016/j.apsoil.2005.02.004

[53] Finkenbein, P., Kretschmer, K., Kuka, K., Klotz, S. and Heilmeier, H. (2013) Soil Enzyme Activities as Bioindicators for Substrate Quality in Revegetation of a Subtropical Coal Mining Dump. Soil Biol. Biochem, 56, 87-89. http://dx.doi.org/10.1016/j.soilbio.2012.02.012

[54] Schimann, H., Petit-Jean, C., Guitet, S., Reis, T., Domenach, A.M. and Roggy, J.C. (2012) Microbial Bioindicators of Soil Functioning after Disturbance: The Case of Gold Mining in Tropical Rainforests of French Guiana. Ecol. Indic, 20, 34-41. http://dx.doi.org/10.1016/j.ecolind.2012.01.021

[55] Ciarkowska, K., Sołek-Podwika, K. and Wieczorek, J. (2014) Enzyme Activity as an Indicator of Soil-Rehabilitation Processes at a Zinc and Lead Ore Mining and Processing Area. J. Environ. Manage, 132, 250-256. http://dx.doi.org/10.1016/j.jenvman.2013.10.022 